TITLE:

\title{
Hydrothermal fluid flow system around the Iheya North Knoll in the mid-Okinawa trough based on seismic reflection data
}

\section{$\operatorname{AUTHOR}(S)$ :}

Tsuji, Takeshi; Takai, Ken; Oiwane, Hisashi; Nakamura, Yasuyuki; Masaki, Yuka; Kumagai, Hidenori; Kinoshita, Masataka; Yamamoto, Fujio; Okano, Tadashi; Kuramoto, Shin'ichi

\section{CITATION:}

Tsuji, Takeshi ...[et al]. Hydrothermal fluid flow system around the Iheya North Knoll in the mid-Okinawa trough based on seismic reflection data. Journal of Volcanology and Geothermal Research 2012, 213-214: 41-50

\section{ISSUE DATE:}

2012-02

URL:

http://hdl.handle.net/2433/153975

\section{RIGHT:}

(C) 2011 Elsevier B.V.; This is not the published version. Please cite only the published version.; この論文は出版社版でありません。引用の際に は出版社版をご確認ご利用ください。 
Hydrothermal fluid paths in continental margin

1 Hydrothermal fluid flow system around the Iheya North Knoll in the

2 mid-Okinawa Trough based on seismic reflection data

4 Takeshi Tsuji $^{1,2}$, Ken Takai $^{2}$, Hisashi Oiwane ${ }^{3}$, Yasuyuki Nakamura ${ }^{3}$, Yuka Masaki ${ }^{2,4}$,

$5 \quad$ Hidenori Kumagai $^{2}$, Masataka Kinoshita ${ }^{2}$, Fujio Yamamoto ${ }^{2}$, Tadashi Okano ${ }^{2}$, and

6 Shin'ichi Kuramoto ${ }^{2}$

7

$8{ }^{1}$ Graduate school of Engineering, Kyoto University

$9 \quad{ }^{2}$ Japan Agency for Marine Earth Science and Technology (JAMSTEC)

$10 \quad{ }^{3}$ Ocean Research Institute, University of Tokyo

$11{ }^{4}$ Department of Applied Science, Kochi University

14 Research Highlights (4 bullet points)

(1) Possible fluid flow paths in the Iheya North Knoll hydrothermal field

(2) Widespread permeable volcanic deposits produced by silicic arc volcanism

(3) Layered sequence focuses migration of fluids derived from trough-fill sediments

(4) Fluid alteration accelerated by interactions with sediments 
24 Abstract

Seismic reflection data around the Iheya North Knoll hydrothermal field provide insights into geological structures that control subseafloor hydrothermal fluid flow in the sediment-covered continental backarc basin of the mid-Okinawa Trough. We identified the seismic expression of widespread porous volcaniclastic pumiceous deposits and intrusions as a result of silicic arc volcanism. The porous and permeable volcanic deposits distribute in an area extending updip from the thick succession of the deep trough to the seafloor at the hydrothermal field. Their regional structure focuses the flow of hydrothermal fluids derived from the surrounding trough-fill sediments and directs them to the vents of the hydrothermal field. The high concentrations of $\mathrm{CH}_{4}$ and $\mathrm{NH}_{4}$ in the fluids of the hydrothermal field are likely derived from the interaction of migrating fluids with trough-fill sediments.

Keywords: Hydrothermal fluid paths, Okinawa Trough, seismic reflection data, 
Hydrothermal fluid paths in continental margin

42

43

\section{Introduction}

The circulation of hydrothermal fluids enhances chemical and thermal exchange and the interaction between the crust and ocean (e.g., Stein and Stein, 1992). Because of the considerable influence of hydrothermal fluid circulation within oceanic lithosphere on the physical, chemical, and biological evolution of the crust and ocean, it has been well studied at spreading axes and on their flanks (e.g., Fisher et al., 1997; Fisher, 1998; Johnson et al., 2000; Fisher et al., 2003; Hutnak et al., 2008; Fisher et al., 2008; Waldhauser and Tolstoy, 2011; Fisher et al., 2011). In contrast, there have been few studies of hydrothermal fluid circulation in subduction zones, such as at island arc submarine volcanoes and in continental backarc basins. Because backarc basins at continental margins are usually covered by thick sequences of terrigenous sediments, an understanding of fluid recharge and migration paths cannot be obtained only from near-seafloor observations.

The hydrothermal field on Iheya North Knoll, about 150 km NNW of Okinawa Island, was discovered in 1995 (Fig. 1; Momma et al., 1996) and has since been investigated during more than 40 dives of manned deep submergence vehicles (DSVs) and remotely operated vehicles (ROVs). These investigations have demonstrated that prosperous subseafloor microbial communities associated with the hydrothermal fluid 
Hydrothermal fluid paths in continental margin

60 chemistry are hosted along the entire hydrothermal fluid flow path, from sedimentary

61 pore water to hydrothermal discharge zones (Nakagawa et al., 2005; Takai et al., 2006).

62 The chemistry of the hydrothermal fluids in the Okinawa Trough (a backarc basin) is

63 unusual among deep-sea hydrothermal fluids studied to date (Ishibashi and Urabe,

64 1995; Gamo et al., 2006; Takai et al., 2006; Takai and Nakamura, 2010; Kawagucci et

al., 2011). High concentrations of $\mathrm{CO}_{2}$ and $\mathrm{CH}_{4}$ are common in fluids in hydrothermal

systems underlying sedimentary sequences, such as at the Juan de Fuca Ridge (Lilley et

al., 1993; Shanks et al., 1995) and in the Guaymas Basin (Welhan and Lupton, 1987;

Pearson et al., 2005). However, the concentrations of $\mathrm{CO}_{2}$ and other gaseous carbon

compounds in hydrothermal fluids from the Okinawa Trough are among the highest in

the world (Gamo, 1995; Konno et al., 2006; Takai and Nakamura, 2010; Kawagucci et

al., 2011). Most of these volatiles are likely derived from subseafloor interactions

between sediments and infiltrated seawater (Kawagucci et al., 2011). In addition, vent

fluids from Okinawa Trough hydrothermal systems have high concentrations of Ba,

provided by hydrothermal reactions between felsic volcanic rocks and hydrothermal

fluids (Gamo et al., 2006). Despite the unusual fluid chemistry of the Okinawa Trough

hydrothermal systems, there has been little investigation of their geological and

hydrogeological setting. Understanding the hydrogeology of hydrothermal systems is of 
Hydrothermal fluid paths in continental margin

78 fundamental importance in studying the interactions among geological, geochemical, and microbial processes in the deep-sea hydrothermal environment of a continental backarc basin. In this study, we investigated the structure of the hydrothermal fluid flow system of the Iheya North Knoll hydrothermal field on the basis of our interpretation of a dense grid of seismic reflection data covering the Iheya North Knoll.

\section{Geologic setting}

The Okinawa Trough lies in the eastern East China Sea, between the Ryukyu Arc -

Trench system and the Eurasian continent (Fig. 1a). In this area, the Okinawa Trough is considered to be in the initial stage of continental rifting, although there is some argument on the commencement and order of the Okinawa Trough rifting (e.g., Letouzey and Kimura, 1985). Most previous studies suggest that rifting commenced in the southern part of the trough (e.g., Sibuet et al., 1995; Hsu et al., 2001) and that it started at $2 \mathrm{Ma}$. The Yangtze River is the main source of the thick terrigenous sediments that cover the crust of the mid-Okinawa Trough (Narita et al., 1990; Huh and

$93 \mathrm{Su}, 1999$ ), where the sedimentation rate has been estimated to be $1-2 \mathrm{~m} \mathrm{ka}^{-1}$ (Tsugaru et al., 1991). 
Hydrothermal fluid paths in continental margin

96 Okinawa Trough $\left(27.8^{\circ} \mathrm{N}, 126.9^{\circ} \mathrm{E}\right.$; Fig. 1$)$ where water depths are greater than $1000 \mathrm{~m}$.

97 The volcanic body of the Iheya North Knoll penetrates through a thick sedimentary

98 sequence and rises about $500 \mathrm{~m}$ above the seafloor. The hydrothermal field lies on the

99 eastern flank of the western peak of the knoll, facing the central valley (Fig. 1c). Several

100 hydrothermal mounds have been recognized during previous surveys (e.g., Takai et al.,

101 2006; Takai and Nakamura, 2010). They are clearly shown in high-resolution

102 bathymetric data (Fig. 2) obtained by autonomous underwater vehicle (AUV) Urashima

103 equipped with acoustic sounding equipment (SeaBat7125, $400 \mathrm{~Hz}$ source) during cruise

104 YK07-07. The hydrothermal mounds are aligned roughly N-S (Fig. 2).

105 The highest temperatures (maximum $311^{\circ} \mathrm{C}$ ) and highest hydrothermal flow rates

106 have been recorded at the vent known as North Big Chimney (NBC; Fig. 2) over a

107 period of more than ten years (e.g., Kawagucci et al., 2011), indicating that the

108 hydrothermal fluid vented from NBC comes from the main hydrothermal flow path in

109 this region. The high temperature of discharged fluid $\left(\sim 300^{\circ} \mathrm{C}\right)$ at NBC suggests a

110 magma-driven system. Both temperatures and flow rates of other vents in the area

111 decrease with increasing distance from NBC (Masaki et al., 2011). Furthermore,

112 intensive hydrothermal plumes have been imaged by side-scan sonar in seawater only

113 around the hydrothermal field (Kumagai et al., 2010). 
Hydrothermal fluid paths in continental margin

114

115

Recent Integrated Ocean Drilling Program (IODP), conducting a series of drill holes in the central valley of the Iheya North Knoll, showed that the sediments there are mainly pelagic and hemipelagic mud and volcaniclastic deposits (pumiceous gravels), and that they have been variably altered by hydrothermal processes (Expedition 331 Scientists, 2010). Drilling data revealed an alternating sequence of hard low-porosity layers and porous layers that were hydrothermally altered at high temperatures. The hard layers, presumably of low permeability, may provide the cap rock above hydrothermal fluid flow paths. The alignment of the active hydrothermal vents along the strike of the sedimentary layers (N-S; Fig. 2) suggests that the hydrothermal fluid flow paths are controlled by the layered sedimentary structures.

\section{Seismic data acquisition and processing}

We used 2D seismic reflection data acquired along 54 survey lines recorded in a dense orthogonal grid during four cruises (Table 1, Figs. 1b and 1c). Multi-channel seismic reflection data were recorded during cruises KY02-11, KY07-03, and KR10-02, and single-channel data during cruise YK06-09. During cruise KR10-02, long-offset $(\sim 4.5 \mathrm{~km})$ multi-channel data were acquired in order to determine the velocity structure required to calculate depths of reflection events. A larger volume airgun was also used 
Hydrothermal fluid paths in continental margin

132

133

134

135

136

137

138

139

140

during cruise KR10-02 (Table 1).

The seismic data from cruises KY02-11 and KY07-03 were processed with a

conventional processing sequence that included spherical divergence correction,

deconvolution, common midpoint (CMP) sorting, normal moveout (NMO) correction, multiple suppression with a Radon filter, CMP stacking, migration, and bandpass

filtering (Yilmaz, 2001). The short streamer deployed during cruises KY02-11 and

KY07-03 (Table 1) did not allow estimation of accurate seismic interval velocities for deep reflectors. However, shallow geological structures were clearly imaged on these profiles (KY02-11 and KY07-03) and the single-channel data (KR06-09), because of the high resolution (high frequency) of the source signals used (Fig. 5).

To obtain accurate depths of subsurface geological structures for data from cruise KR10-02, we applied prestack depth migration incorporating an iterative horizon-based tomographic analysis of seismic velocity (see Figs. 3 and 4). We determined seismic velocities at six horizons, including the sediment-crust interface. Because the dominant frequency of the cruise KR10-02 data was lower than that of the other cruises, we used these data mainly for interpretation of the deep geological structure (Figs. 3 and 4). Although 2D seismic reflection data do not unequivocally resolve structures in 3D (French, 1974), the dense grid of orthogonal profiles we used allowed us to identify the 
Hydrothermal fluid paths in continental margin

150 3D subseafloor structures with reasonable confidence. Furthermore, by comparing

151 orthogonal profiles we were able to identify sideswipe reflections from nearby areas of

152 elevated seafloor. Because the seismic interval velocities necessary for depth conversion

153 could not be accurately determined within the knoll, we used 3D fence diagrams

154 constructed from several time-domain reflection profiles (Fig. 6) to develop a

155 representation of both subseafloor geological structures and possible hydrothermal fluid

156 paths.

To interpret and characterize the subseafloor structures (e.g., volcanic deposits), we calculated seismic attributes (e.g., amplitude envelope; Fig. 7) (Taner et al., 1979; Tsuji et al., 2005). Magmatic intrusions can be imaged as blocks on the envelope profile (Fig. 7) mainly because the envelope ignores phase information; the intrusions disturb the original structure of sedimentary sequence (Tsuji et al., 2007).

4. Volcanic activity and pumiceous deposits

The seismic profiles across the Iheya North Knoll reveal the subseafloor volcanic and sedimentary structures in the area under and surrounding the knoll. The subseafloor rocks of the Iheya North Knoll volcano are characterized by chaotic reflections that extrude through trough sediments of $>1500 \mathrm{~m}$ thickness (Figs. 3 and 4 ). The depth of 
Hydrothermal fluid paths in continental margin

168 the seafloor around the knoll is greater on the southwestern side of the knoll (Figs. 3 and

169 4) because of ongoing tectonic rifting in the Okinawa Trough. The seismic reflection

170 profiles did not allow us to identify a heat source beneath the knoll because the complicated subsurface structure and steep seafloor terrain of the knoll made it difficult

172 to resolve deep structures. The magma reservoir probably lies below the knoll at a depth

173 beyond the resolution of our seismic data. However, southwest of the knoll we

174 identified strong low-frequency reflectors beneath the trough sediments ( $\sim 4 \mathrm{~km}$ below seafloor; red arrows in Fig. 4) that possibly represent a magmatic body. Numerous normal faults are developed in the sediments overlying the possible magmatic body and dip toward it (Fig. 4). reflections at and beneath the seafloor (Fig. 7a), including the peak east of the central valley (Fig. 5a). This seismic transparency indicates a lack of acoustic impedance contrast over these intervals, indicating that they represent intervals of homogeneous and porous rock. Piston cores obtained at the peak above the transparent interval during cruise KY08-01 (labeled A in Figs. 1c and 7a) are composed of volcaniclastic pumiceous deposits interbedded with silt (Oiwane et al., 2008), which would be expected to be seismically transparent. Thus, the transparent intervals likely represent 
Hydrothermal fluid paths in continental margin

186

187

188

189

190

191

192 (complex network of volcanic deposits) within trough sediment.

volcaniclastic pumiceous deposits. thick submarine volcaniclastic deposits, lava flows, or sills. Furthermore, a

around the Iheya North Knoll (Expedition 331 Scientists, 2010). In the central valley of the Iheya North Knoll (the depression east of the hydrothermal field; Fig. 2), piston cores revealed several pumice layers of $\sim 10 \mathrm{~cm}$ thickness within $3 \mathrm{~m}$ below the seafloor (labeled B in Figs. 1c and 5b) (Oiwane et al., 2008). On the eastern side of the knoll, a volcaniclastic layer of about $40 \mathrm{~cm}$ thickness is interbedded within an approximately 5-m-thick sequence of mud-dominated trough sediments (labeled C in Fig. 1c). Our seismic data cannot resolve such thin pumiceous layers (e.g., Rayleigh’s criterion; Sheriff, 2002). However, we noted high-amplitude reflectors extending horizontally away from the Iheya North Knoll (white dashed lines in Fig. 7b), some of which are discordant with the layered sedimentary sequence in the trough. These may represent low-frequency, high-amplitude reflection at the seafloor trace of a normal fault (gray dashed line in Fig. 7c) may represent a magmatic body extruded on the seafloor after upwelling via the normal fault. This observation also explains frequent intrusions 
Hydrothermal fluid paths in continental margin

204

205

206

207

208

209

210

211

212

213

\section{Reservoir formation and hydrothermal fluid pathways}

\subsection{Small-scale fluid circulation}

In the central valley of the Iheya North Knoll, there are repetitive east-dipping

seismic reflectors within the sediments immediately below the seafloor (Fig. 5b),

suggesting the existence of a layered sedimentary structure. Core samples demonstrate that the layered structure within this sedimentary sequence includes high-permeability pumiceous flow deposits (Oiwane et al., 2008; Expedition 331 Scientists, 2010). The permeability of the pumiceous gravels (Nakamura et al., 2008) obtained during drilling (Expedition 331 Scientists, 2010) was considerably higher than that of the mud-dominated pelagic sediments. Therefore, these highly permeable volcanic sequences might provide lateral migration pathways for pore fluids. Furthermore, the lateral distribution of high-permeability (pumiceous) layers overlain by low-permeability (pelagic and hemipelagic mud) layers may trap the fluid and provide reservoirs for subseafloor hydrothermal fluids. Whereas, this sedimentary sequence is also intersected by numerous steep normal faults, which might provide pathways for vertical (rather than lateral) flow of hydrothermal fluids. Pyroclastic flow deposits may exist below the 200-m-thick layered sedimentary sequence that includes low-permeability mud, in the sequence between the black and 
Hydrothermal fluid paths in continental margin

222

223

224

225

226

227

228

229

230

231

232

233

gray diamonds in Fig. 5b. This porous, high-permeability sequence dips basinward from the volcanic body near the hydrothermal field, and may provide a path for hydrothermal fluids to migrate laterally up the slope. Furthermore, the N-S trend of the vents of the hydrothermal field at the western edge of the low-permeability central valley sediments (Fig. 2) corresponds to the trend of the seafloor outcrop of the pyroclastic deposits (Fig. 5b), which supports the view that they may provide a conduit for hydrothermal fluid flow.

As one of the possible recharge entries around the central valley, a linear volcanic ridge located at $\sim 2 \mathrm{~km}$ east of the hydrothermal vent sites ( $\sim 30 \mathrm{~m}$ high and $500 \mathrm{~m}$ wide; Figs. 2, 5b and 8) is suggested on the basis of the heat flow measurements (Masaki et al., 2011). Numerous heat flow data in the region of the knoll have shown temperature increasing with depth, but heat flow data from the sediments on the volcanic ridge reveal an inverse gradient (Masaki et al., 2011). Furthermore, the heat flow values increase gradually with distance from the ridge, reaching a maximum at the hydrothermal vents. The weak seafloor reflection of the volcanic ridge (Fig. 5b) suggests a porous volcaniclastic pumiceous seafloor there. Therefore, the ridge may provide an entry for recharge of hydrothermal fluids in the pyroclastic flow deposits beneath the central valley. 
Hydrothermal fluid paths in continental margin

If the volcanic ridge provides the primary hydrothermal fluid source at Iheya North

241 Knoll, the hydrothermal fluid circulation cell is small, with only a few kilometers

242 separating the main recharge and discharge areas (Fig. 5b). A circulation cell of this

243 scale is comparable to those characteristic of fast-spreading mid-ocean ridges, where

244 fluid residence times on the order of several to ten years have been estimated. A

245 circulation cell of this scale would not sustain the steady hydrothermal fluid discharge,

246 its chemistry, and the associating enormous chemosynthetic microbial and faunal

247 communities of the Iheya North Knoll hydrothermal field (Nakagawa et al., 2005; Takai

248 et al., 2006; Takai and Nakamura, 2010; Kawagucci et al., 2011). In particular, the

249 carbon mass balance between hydrothermal fluid discharges and inorganic and organic

250 carbon sources in the volcanic deposits and sediments within the Iheya Knoll structure

251 clearly indicate that the hypothesized hydrothermal fluid paths could not support the

$252 \mathrm{CH}_{4}$ mass balance and stable isotope composition of the discharging hydrothermal

253 fluids (Kawagucci et al., 2011). Thus, there must be other sources and pathways of

254 hydrothermal fluids discharging at the Iheya North Knoll hydrothermal field.

\subsection{Large-scale fluid circulation}


Hydrothermal fluid paths in continental margin

258 beneath Iheya North Knoll, the eastern end of which approaches the seafloor near the

260 profile (KY0703-E), this strong reflector dips to the north away from the hydrothermal

261 field (black circles in Fig. 5e). The high reflection amplitude (Fig. 5b) of this continuous

262 reflector may represent an important boundary that controls hydrothermal fluid flow

263 paths. The 3D structure of this reflector determined from our fence diagram of

264 orthogonal seismic profiles (Fig. 6) indicates that it extends away from the knoll to the

265 north and west, and that the shallowest part of the horizon converges on the

266 hydrothermal field. Furthermore, we noted several reflectors below and parallel to the

267 strong reflection, indicating a layered structures (gray circles in Figs. 5b and 5e). The

268 polarity of the strong west-dipping reflector is opposite to that of the seafloor reflector

269 (Fig. 5c), which indicates that the seismic velocity below the negative-polarity reflector

270 is lower than that of the overlying sequence. DSV and ROV observations of the small

271 peak immediately west of the hydrothermal field (e.g., NT07-11 cruise; Fig. 2) indicate

272 that most of the seafloor there is paved with potential sheet carbonate crust containing numerous mussel shells and pieces of pumiceous breccia (Figs. 5b and 8). Based on the pumiceous volcanic structures exposed at the seafloor and the layered structures below and parallel to the negative-polarity reflector (gray circles in Fig. 5b), we interpret the 
Hydrothermal fluid paths in continental margin

276 negative-polarity reflector and underlying low-velocity sequence to represent porous

277 volcanic breccia.

278 Because the permeability of the layered sequence underlying the negative-polarity

279 horizon is likely higher than those above and below it, large-scale permeability

280 anisotropy would be expected within the layered sequence; low-permeability sediments

281 above the layered sequence would provide a cap structure to prevent vertical upward

282 migration of fluids. Furthermore, as already pointed out, the shallow eastern extent of

283 the negative-polarity reflector approaches the hydrothermal field (Fig. 6). Thus, we

284 suggest that the layered sequence immediately below the negative-polarity reflector

285 provides a major conduit that gathers hydrothermal fluids and channels them to their

286 point of discharge at the Iheya North Knoll hydrothermal field.

287 The large number of dead mussel shells on the seafloor above the shallowest point

288 of the negative-polarity reflector (Figs. 2, 5b, and 8) suggest that past methanotrophic

289 mussel populations was sustained by considerable amounts of hydrothermally derived

290 methane seepage. The seafloor reflector above the negative-polarity reflector is stronger

291 than that of the surrounding seafloor (Fig. 5e), suggesting that a consolidated carbonate

292 crust is exposed at the seafloor there. Although it is still unclear how old the mussel

293 shells and carbonate crust are formed, the volatile components of the hydrothermal 
Hydrothermal fluid paths in continental margin

294 fluids such as $\mathrm{CO}_{2}$ and $\mathrm{CH}_{4}$ would escape from the hydrothermal reservoir by diffusion

295 through the cap structure above the negative-polarity reflector, which may have been a

296 less-effective seal in the past.

297 As shown by both the E-W and N-S seismic profiles, the negative-polarity event

298 and underlying layered sequence extend into the thick trough-fill sediments that are

299 widespread on the western and northern sides of the Iheya North Knoll (Figs. 5b and 5e).

300 Considering the 3D structure of the negative-polarity horizon (Fig. 6), the large

301 reservoir of pore water in the thick trough-fill sediments may provide the source of

302 hydrothermal fluids, which then flow updip within the continuous permeable layered

303 sequence before discharging at Iheya North Knoll hydrothermal field. Both the

304 sedimentary sequence and the interbedded volcanic units were uplifted by the volcanic

305 intrusion that formed the knoll. The resultant structure and the presence of a heat source

306 beneath the knoll facilitate lateral migration of recharged fluids along the pumiceous

307 layers toward the hydrothermal field. This conceptual hydrothermal system is consistent

308 with the extraordinarily high concentrations of $\mathrm{CH}_{4}$ and $\mathrm{NH}_{4}$ in the hydrothermal fluids

309 of the Iheya North Knoll hydrothermal field (Kawagucci et al., 2011). Rather, it is

310 consistent with the prediction that the abundant $\mathrm{CH}_{4}$ and $\mathrm{NH}_{4}$ in the hydrothermal fluid

311 should be derived from their reservoir in the more organics-rich, trough-filling 
Hydrothermal fluid paths in continental margin

sediments accumulated by subseafloor microbial methanogenesis and ammonification in certain geological time scales (Kawagucci et al., 2011).

We identified many normal faults within the trough-fill sediments around the Iheya North Knoll (Fig. 4). The major faults strike parallel to the trough axis (ENE-WSW). Although the lithology is the same on both sides of a major normal fault on line YK-0703-18, the reflection amplitude east of the fault is weaker than that west of the fault (Fig. 7b). If the normal fault creates a hydrogeological boundary to lateral flow, the higher amplitudes west of the fault might represent active hydrothermal fluid flow and/or gas trapped within sedimentary sequence near the knoll. On the other hand, these major normal faults extend from the seafloor to deep crustal basement (Figs. 3 and 4; Lee et al., 1980) and, if fluid flow is driven by thermal advection from the deep heat source beneath the Iheya North Knoll, it is also possible that these deep crustal faults provide vertical hydrothermal fluid migration paths (Fig. 8).

\section{Discussion and conclusions}

In the region of mid-ocean ridges, the primary conduits for hydrothermal fluids are highly permeable zones of upper oceanic crust and abyssal-hill faults (Fisher, 1998;

Fisher and Becker, 2000; Fisher et al., 2008; Hutnak et al., 2008; Fisher et al., 2011). 
Hydrothermal fluid paths in continental margin

330 The thick sedimentary sequences that overlie basaltic crust on the flanks of mid-ocean

331 ridges are generally considered to be impermeable to hydrothermal fluid flow. However,

332 unlike the high-temperature fluids in sediment-hosted hydrothermal vent fields, the

333 hydrothermal fluids there are not highly enriched with $\mathrm{CH}_{4}$ and $\mathrm{NH}_{4}$ (Wheat et al., 2003,

334 2004). A plausible explanation for this difference is that the primary fluid source on the

335 ridge flank is nutrient-poor oxygenated seawater recharged directly through volcanic

336 outcrops on the seafloor (Fisher et al., 2003) such that the chemistry of the

337 hydrothermal fluids is little affected by geochemical and microbiological alteration

338 during migration.

339 The Iheya North Knoll hydrothermal system is part of a continental backarc basin

340 where subseafloor silicic arc volcanic deposits provide complex migration networks for

341 recharge and discharge of sediment pore fluids. Taking into consideration the

342 extraordinary $\mathrm{CH}_{4}$ and $\mathrm{NH}_{4}$ enrichment of the fluids of the Iheya North Knoll

343 hydrothermal field, there are four important components in the model we propose here

344 for the hydrothermal fluid flow system.

1. The primary source of hydrothermal fluids is the nutrient-rich, reductive pore fluids of the trough-fill sediments around the Iheya North Knoll.

347 2. The primary fluid recharge and migration paths are through permeable trough-fill 
Hydrothermal fluid paths in continental margin

volcaniclastic sediments and normal faults that extend from the seafloor to crustal basement.

3. Geochemical and microbiological alteration of hydrothermal fluids passing through the complex network of flow paths enriches them in $\mathrm{CH}_{4}$ and $\mathrm{NH}_{4}$.

4. The structural culmination around the knoll of the highly permeable volcaniclastic sequences that integrate multiple flow paths focuses fluid flow in the region of the hydrothermal vents.

Acknowledgements

We thank CDEX/JAMSTEC and Nippon Marine Enterprises (NME) for the acquisition

and Y. Kido and S. Uraki (CDEX/JAMSTEC) for their cooperation and assistance in

"Structure of oceanic crust and its properties revealed by seismic reflection method:

Insight into subseafloor hydrothermal fluid circulation” (21109502) and the Excellent

Science (21-5338). 
Hydrothermal fluid paths in continental margin

366

367

368

References

369

Expedition 331 Scientists, 2010. Deep hot biosphere. IODP Prel. Rept. 331.

370 doi:10.2204/iodp.pr.331.2010.

371

Fisher, A. T., 1998. Permeability within basaltic oceanic crust, Rev. Geophys. 36, 143-182.

Fisher, A.T., Becker, K., 2000. Reconciling heat flow and permeability data with a model of channelized flow in oceanic crust, Nature 403, 71-74.

Fisher, A.T., Becker, K., Davis, E.E., 1997. The permeability of young oceanic crust east of Juan de Fuca Ridge determined using borehole thermal measurements. Geophys. Res. Lett. 24, 1311-1314.

Fisher, A.T., Davis, E.E., Hutnak, M., Spiess, V., Zuhlsdorff, L., Cherkaoui, A., Christiansen, L., Edwards, K., Macdonald, R., Villinger, H., Mottl, M.J., Wheat, C.G., Becker, K., 2003. Hydrothermal recharge and discharge across50 km guided by seamounts on a young ridge flank, Nature, 421, 618-621, doi:10.1038/nature01352. 
Hydrothermal fluid paths in continental margin

384

385

386

387

388

389

390

391

392

393

394

395

396

397

398

399

400

401

across $2.4 \mathrm{~km}$ in the upper oceanic crust: Implications for crustal-scale properties, J. Geophys. Res., 113, B07106, doi:10.1029/2007JB005447.

Fisher, A.T., Tsuji, T., Petronotis, K., and the Expedition 327 Scientists, 2011. Proc.

IODP, 327: Tokyo (Integrated Ocean Drilling Program Management International, Inc.). doi:10.2204/iodp.proc.327.2011.

French, W.S., 1974. Two-dimensional and three-dimensional migration of model-experiment reflection profiles, Geophysics, 39, 265-277.

Gamo, T., 1995. Wide variation of chemical characteristics of submarine hydrothermal fluids due to secondary modification processes after high temperature water-rock interaction: a review. p. 425-451. In H. Sakai, and Y. Nozaki (eds.), Biogeochemical processes and ocean flux in the western Pacific, Terra Scientific Publisher, Tokyo.

Gamo, T., Ishibashi, J., Tsunogai, U., Okamura, K., Chiba, H., 2006. Unique geochemistry of submarine hydrothermal fluids from arc-backarc settings of the western Pacific. In "Back-Arc Spreading Systems: Geological, Biological, Chemical, and Physical Interactions" (D. M. Christie, C. R. Fisher, S.-M. Lee and S. Givens ed.) AGU Monograph series, 166, 147-161.

Hsu, S.-K., Sibuet, J.-C. Shyu C.-T., 2001. Magnetic inversion in the East China Sea 
Hydrothermal fluid paths in continental margin

and Okinawa Trough: tectonic implications, Tectonophysics, 333, 111-122.

Huh, C.A., Su, C.C., 1999. Sedimentation dynamics in the East China Sea elucidated from ${ }^{210} \mathrm{~Pb},{ }^{137} \mathrm{Cs}$ and ${ }^{239,240} \mathrm{Pu}$, Mar. Geol., $160,183-196$.

Hutnak, M., Fisher, A.T., Harris, R., Stein, C., Wang, K., Spinelli, G., Schindler, M., Villnger, H., Silver, E., 2008. Large heat and fluid fluxes driven through mid-plate outcrops on ocean crust, Nature Geoscience, 1, 611-614.

Ishibashi, J., Urabe, T., 1995. Hydrothermal activity related to arc-backarc magmatism in the western Pacific, In Backarc Basins: Tectonics and Magmatism, Ed. B Taylor, Plenum Press, New York, 451-495.

Johnson, H.P., Hutnak, M., Dziak, R.P., Fox, C.G., Urcuyo, I., Cowen, J.P., Nabelek, J., Fisher, C., 2000. Earthquake-induced changes in a hydrothermal system on the Juan de Fuca mid-ocean ridge, Nature, 407, 174-177.

Kawagucci, S., Chiba, H., Ishibashi, J., Yamanaka, T., Toki, T., Muramatsu, Y., Ueno, Y., Makebe, A., Inoue, K., Yoshida, N., Nakagawa, S., Nunoura, T., Takai, K., Takahata, N., Sano, Y., Narita, T., Teranishi, G., Obata, H., and Gamo, T., 2011. Hydrothermal fluid geochemistry at the Iheya North field in the mid-Okinawa Trough: Implication for origin of methane in subseafloor fluid circulation systems, Geochem. J., 45, 109-124. 
Hydrothermal fluid paths in continental margin

420

421

422

423

424

425

426

427

428

429

430

431

432

433

434

435

436

437

Konno, U., Tsunogai, U., Nakagawa, F., Nakaseama, M., Ishibashi, J., Nunoura, T., Nakamura, K., 2006. Liquid CO2 venting on the seafloor: Yonaguni Knoll IV hydrothermal system, Okinawa Trough, Geophys. Res. Lett., 33, L16607, doi:10.1029/2006GL026115.

Kumagai, H., Tsukioka, S., Yamamoto, H., Tsuji, T., Shitashima, K., Asada, M., Yamamoto, F., and Kinoshita, M., 2010. Hydrothermal plumes imaged by high resolution side - scan sonar on a cruising AUV, Urashima, Geochem. Geophys. Geosyst., 11, Q12013, doi:10.1029/2010GC003337.

Lee, C., Shor, G.G., Bibee, L.D., Lu, R.S., Hilde, T.W.C., 1980. Okinawa Trough, origin of a back-arc basin, Mar. Geol., 35, 219-241.

Letouzey, J., Kimura, M., 1986. Okinawa Trough: genesis of a back-arc basin developing along a continental margin, Tectonophysics, 125, 209-230.

Lilley, M.D., Butterfield, D.A., Olson, E.J., Lupton, J.E., Macko, S.A., Mcduff, R.E., 1993. Anomalous CH4 and NH4+ concentrations at an unsedimented mid-ocean-ridge hydrothermal system, Nature, 364, 45-47.

Masaki, Y., Kinoshita., M, Inagaki,_F., Nakagawa, S., Takai, K., 2011. Possible kilometer-scale hydrothermal circulation within the Iheya-North field, mid-Okinawa Trough, as inferred from heat flow data, JAMSTEC Rep. Res. Dev., 12, 1-12 
Hydrothermal fluid paths in continental margin

Momma, H., Iwase, R., Mitsuzawa, K., Kaiho, Y., Fujiwara, Y., Amitani, Y., Aoki, M., 1996. Deep tow survey in Nanseisyoto region (K95-07-NSS), JAMSTEC J

$$
\text { Deep-sea Res., 12, 195-210 (in Japanese with English abstract). }
$$

Nakagawa, S., Takai, K., Inagaki, F., Chiba, H., Ishibashi, J., Kataoka, S., Hirayama, H., Nunoura, T., Horikoshi, K., Sako, Y., 2005. Variability in microbial community and venting chemistry in a sediment-hosted backarc hydrothermal system: impacts of subseafloor phase-separation, FEMS Microbiol. Ecol., 54, 141-155.

Nakamura, M., Otakia, K. and Takeuchi, S., 2008. Permeability and pore-connectivity variation of pumices from a single pyroclastic flow eruption: Implications for partial fragmentation, Journal of Volcanology and Geothermal Research, 176, 302-314.

Narita, H., Harada, K., Tsunogai, S., 1990. Lateral transport of sediment in particles in the Okinawa Trough determined by natural radionuclides, Geochem J., 24, 207-216.

Oiwane, H., Kumagai, H., Masaki, Y., Nakamura, Y., Tokuyama, H., 2008. Characteristics of Sediment in Iheya North Knoll and 'the acoustic blanking layer, JPGU meeting, J164-P013 (English abstract).

Pearson, A., Seewald, J.S., Eglinton, T.I., 2005. Bacterial incorporation of relict carbon in the hydrothermal environment of Guaymas Basin, Geochim. Cosmochim. Acta, 69, 5477-5486. 
Hydrothermal fluid paths in continental margin

456

457

458

459

460

461

462

463

464

465

466

467

468

469

470

471

472

473

Shanks W.C., Bohlke, J.K., Seal, R.R., 1995. Stable isotopes in Mid-Ocean Ridge

hydrothermal systems: interactions between fluids, minerals and organisms, p.

194-221. In S.E. Humphris, R.A. Zierenberg, L.S. Mullineaux, and R.E. Tompson

(eds.), Geophysical Monograph 91 Seafloor Hydrothermal System, American

Geographical Union, Washington DC.

Sheriff, R.E., 2002. Encyclopedic Dictionary of Exploration Geophysics, Geophys. Ref.

Ser., vol. 13, 4th ed., Soc. of Explor. Geophys., Tulsa, Okla.

Sibuet, J.-C., Hsu, S.-K., Shyu, C.-T., Liu, C.-S., 1995. Structural and kinematic

evolution of the Okinawa trough backarc basin. In: Taylor, B. (Ed.), Backarc

Basins: Tectonics and Magmatism. Plenum, New York, pp. 343- 378.

Stein, C., Stein, S., 1992. A model for the global variation in oceanic depth and heat flow with lithospheric age, Nature, 359, 123-129.

Takai, K., and Nakamura, K., 2010. Compositional, Physiological and Metabolic Variability in Microbial Communities Associated with Geochemically Diverse, Deep-Sea Hydrothermal Vent Fluids, L.L. Barton et al. (eds.), Geomicrobiology: Molecular and Environmental Perspective, Springer Netherlands.

Takai, K., Nakagawa, S., Reysenbach, A.-L., Hoek, J., 2006. Microbial ecology of Mid-Ocean Ridges and Back-Arc Basins. In "Back-Arc Spreading Systems: 
Hydrothermal fluid paths in continental margin

474

475

476

477

478

479

480

481

482

483

484

485

486

487

488

489

490

491

Geological, Biological, Chemical, and Physical Interactions" (D. M. Christie, C. R.

Fisher, S.-M. Lee and S. Givens ed.) AGU Monograph series, 166, 185-213.

Taner, M. T., Koehler, F., Sheriff, R.E., 1979. Complex seismic traces analysis, Geophysics, 44, 1041- 1063.

Tsugaru, R., Tamaki, Y., Sato, M., Kimura, M., Shimamura, K., 1991. Report on DELP 1988 cruises in the Okinawa Trough: part4, Preliminary report on the sediment samples, Bull Earthq. Res. Inst., 66, 71-89.

Tsuji, T., Matsuoka, T., Yamada, Y., Nakamura, Y., Ashi, J., Tokuyama, H., Kuramoto, S., Bangs, N., 2005. Initiation of plate boundary slip in the Nankai Trough off the Muroto peninsula, southwest Japan, Geophys. Res. Lett., 32, L12306, doi:10.1029/2004GL021861.

Tsuji, T., Nakamura, Y., Tokuyama, H., Coffin, M.F., Koda, K., 2007. Oceanic crust and Moho of the Pacific Plate in the eastern Ogasawara Plateau region, Island Arc, 16, 361-373.

Waldhauser, F., and Tolstoy, M., 2011. Seismogenic structure and processes associated with magma inflation and hydrothermal circulation beneath the East Pacific Rise at 950’ N, Geochem. Geophys. Geosyst., 12, Q08T10, doi:10.1029/2011GC003568.

Welhan, J. A., Lupton, J.E., 1987. Light hydrocarbon gases in Guaymas Basin 
Hydrothermal fluid paths in continental margin

492

493

494

495

496

497

498

499

500

501

502

503

504

505

506

507

508

509 hydrothermal fluids: Thermogenic versus abiogenic origin, Amer. Assoc. Petrol.

Geol. Bull., 71, 215-223.

Wheat, C.G., Jannasch, H.W., Kastner, M., Plant, J.N., DeCarlo, E.H., 2003. Seawater transport and reaction in upper oceanic basaltic basement: chemical data from continuous monitoring of sealed boreholes in a mid-ocean ridge flank environment, Earth Planet. Sci. Lett., 216, 549-564.

Wheat, C.G., Jannasch, H.W., Kastner, M., Plant, J.N., DeCarlo, E.H., Lebon, G., 2004. Venting formation fluids from deep sea boreholes in a ridge flank setting: ODP Sites 1025 and 1026, Geochem. Geophys. Geosyst., 5, Q08007, doi:10.1029/2004GC000710.

Yilmaz, O., 2001. Seismic Data Processing: Processing, Inversion, and Interpretation of Seismic Data, Invest. Geophys. Ser., vol. 10, 2nd ed., edited by S. M. Doherty, Soc. of Explor. Geophys., Tulsa, Okla. 
Hydrothermal fluid paths in continental margin

510

511

512

513

Table 1. Acquisition parameters for seismic surveys

514

\begin{tabular}{|c|c|c|c|c|}
\hline Cruise & Vessel & Survey lines & Streamer & Source \\
\hline KY02-11 & R/V Kaiyo & 2 lines & $\begin{array}{c}\text { 24-channel, } \\
600 \text { m streamer }\end{array}$ & $\begin{array}{c}\sim 2.5 \mathrm{~L}\left(150 \text { inch }^{3}\right) \\
\text { GI airgun }\end{array}$ \\
\hline YK06-09 & $R / V$ Yokosuka & 26 lines & $\begin{array}{l}\text { 1-channel } \\
\text { Streamer }\end{array}$ & $\begin{array}{c}\sim 2.5 \mathrm{~L}\left(150 \text { inch }^{3}\right) \\
\text { GI airgun }\end{array}$ \\
\hline KY07-03 & $R / V$ Kaiyo & 19 lines & $\begin{array}{c}\text { 48-channel, } \\
1200 \text { m streamer }\end{array}$ & $\begin{array}{c}\sim 5.8 \mathrm{~L}\left(355 \text { inch }^{3}\right) \\
\text { GI airgun }\end{array}$ \\
\hline KR10-02 & $R / V$ Kairei & 7 lines & $\begin{array}{c}\text { 360-channel } \\
4500 \text { m streamer }\end{array}$ & $\begin{array}{c}\sim 54 \mathrm{~L}\left(3300 \text { inch }^{3}\right) \\
\text { Tuned airgun }\end{array}$ \\
\hline
\end{tabular}

515

516

517

518

519

520

521

522

523 
Hydrothermal fluid paths in continental margin

Figure Captions
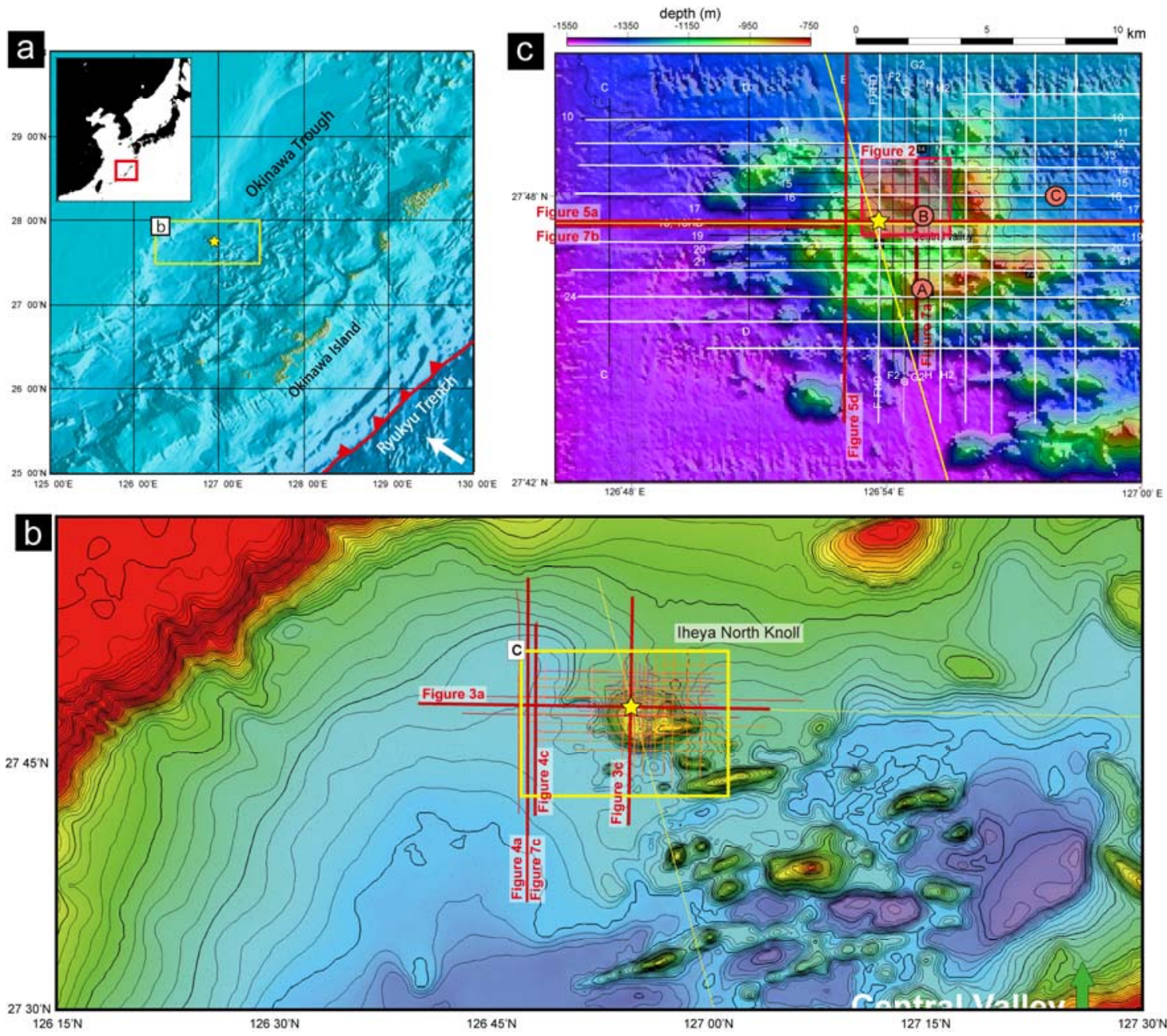

525

Figure 1. (a) Location map and bathymetry of the Okinawa Trough. (b)

527 Bathymetric map of the Iheya North Knoll area showing seismic survey lines

used in this study. The yellow star shows the location of the hydrothermal field.

529 The seismic profiles displayed in Figures 3, 4, and 7 are shown as thick red lines.

530 (c) Enlarged bathymetric map of the Iheya North Knoll area with seismic survey

531 lines shown. The seismic profiles displayed in Figures 5 and 7 are shown as

532 thick red lines. 
Hydrothermal fluid paths in continental margin

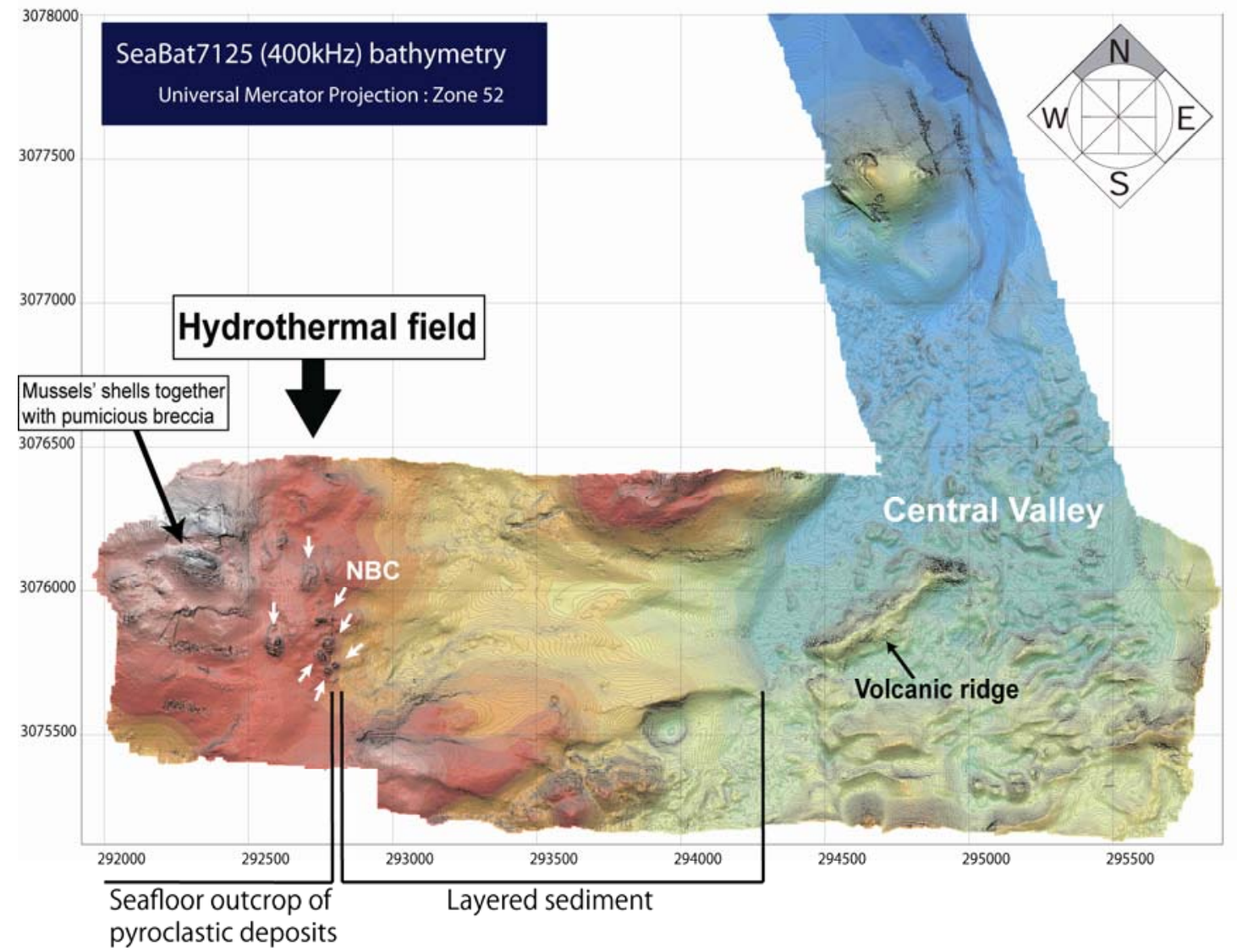

534 Figure 2. Bathymetric map of the central valley within the Iheya North Knoll acquired by AUV Urashima during cruise YK07-07. White arrows indicate hydrothermal mounds. The volcanic ridge in the central valley and the peak on the western side of the hydrothermal field are also shown. 
Hydrothermal fluid paths in continental margin
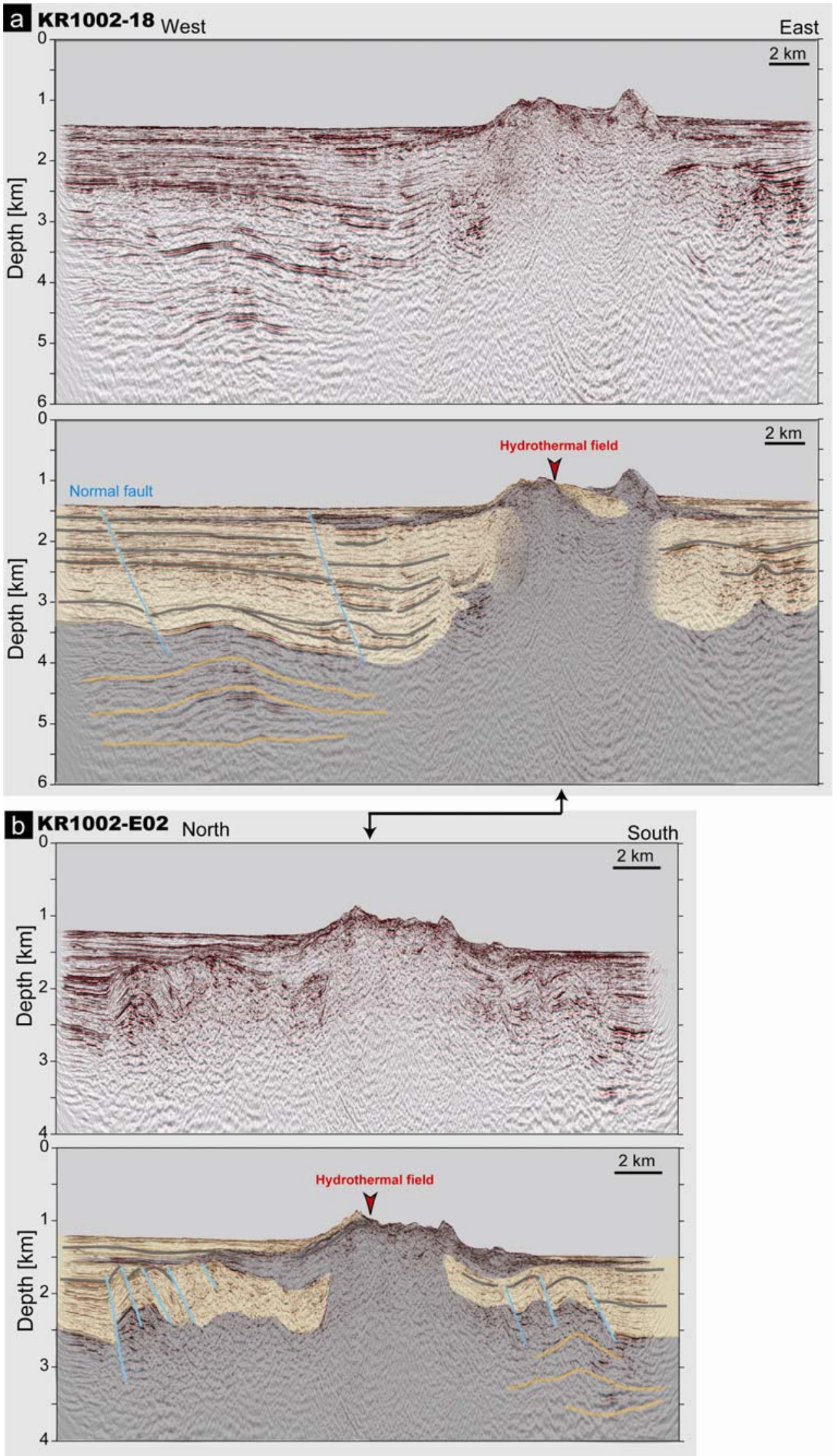
Hydrothermal fluid paths in continental margin

$540 \quad$ Figure 3. Prestack depth migrated seismic profiles across the Iheya North Knoll

541 hydrothermal field with and without geological interpretation. (a) E-W line

542 KR1002-18 and (b) N-S line KR1002-E2. Locations of the profiles are shown in

543 Figure 1b. The two profiles intersect at the Iheya North Knoll hydrothermal field

544 (red arrow). Gray shaded areas indicate volcanic bodies or deposits with high

545 permeability. Gray lines indicate geological boundaries, some of which are

546 pumiceous deposits. The normal faults indicated by blue lines. 


\section{Hydrothermal fluid paths in continental margin}
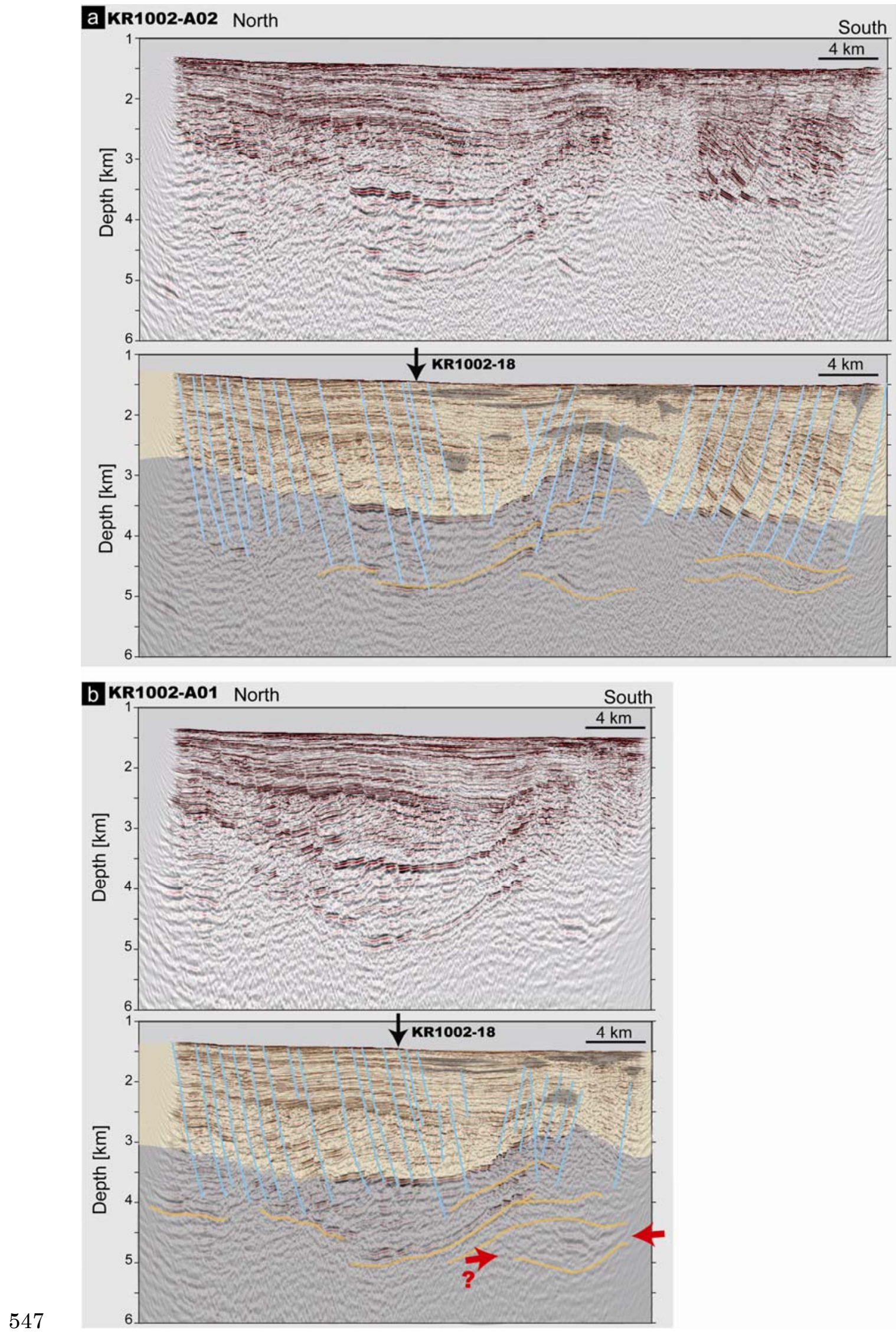
Hydrothermal fluid paths in continental margin

548 Figure 4. N-S prestack depth migrated seismic profiles (with and without

549 geological interpretation) west of the Iheya North Knoll, showing intense normal

550 faulting. (a) Line KR1002-A02 and (b) line KR1002-A01. Locations of the profiles

551 are shown in Figure 1b. Normal faults (blue lines) may provide fluid recharge

552 paths to the deep crust. Red arrows indicate the location of a possible magma

553 chamber.

554

555 


\section{Hydrothermal fluid paths in continental margin}
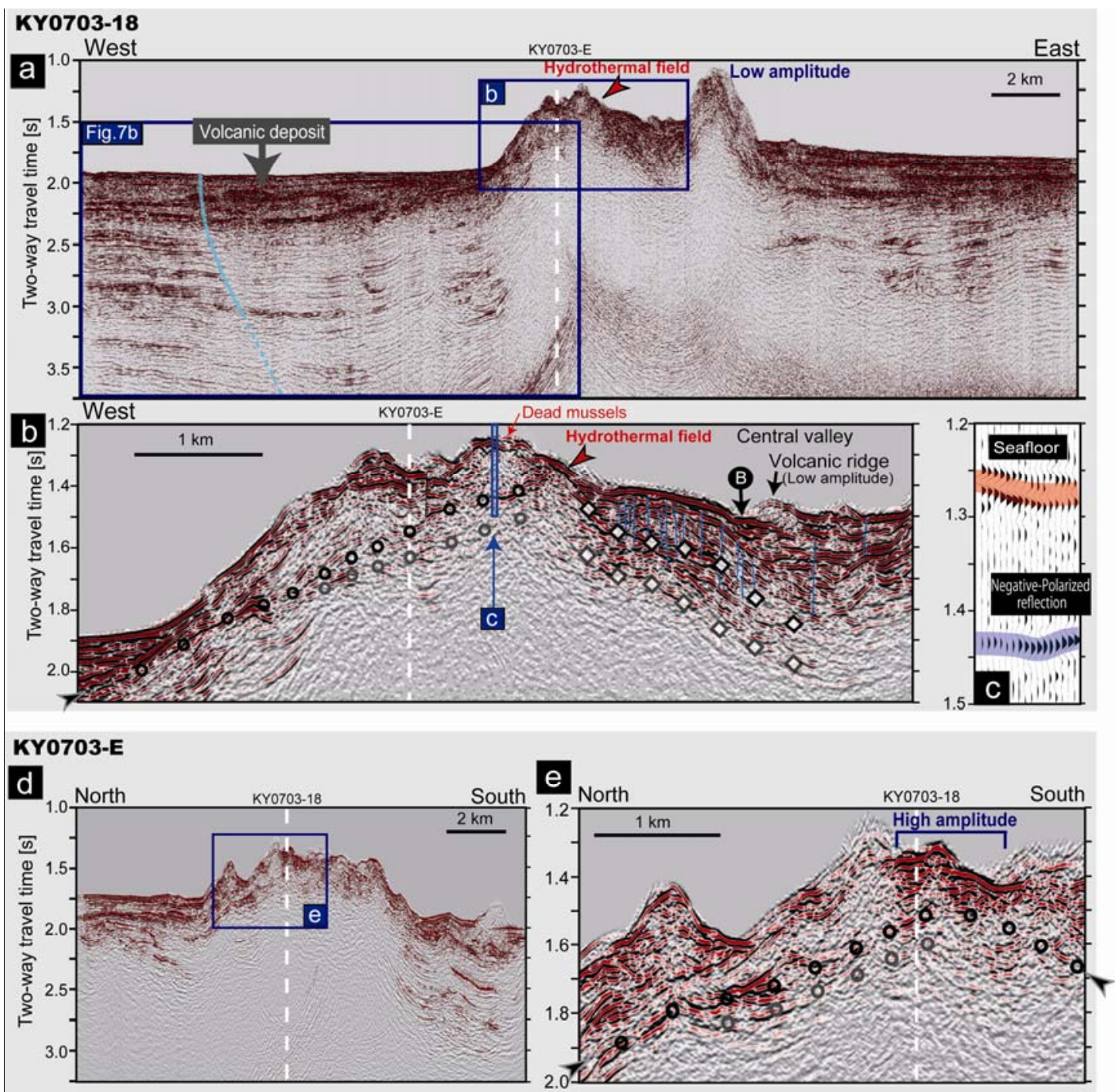

557 Figure 5. Interpreted time-domain seismic reflection profiles around the Iheya

558 North Knoll hydrothermal field. Locations of the profiles are shown in Figure 1c.

559 No amplitude gain control (AGC) was applied during processing of these

561 white dashed lines indicate the intersection of the two profiles. Panels (b) and (e)

562 show enlargements from profiles KY0703-18 and KY0703-E, respectively. Black

563 circles indicate negative-polarity reflections. Gray circles indicate reflections 
Hydrothermal fluid paths in continental margin

564 parallel to the negative-polarity reflections. Black diamonds indicate the upper

565 surface of pyroclastic flow deposits. Gray diamonds indicate the base of

566 pyroclastic flow deposits. (c) Enlargement of panel (b) showing a seafloor

567 reflection wavelet and a negative-polarity reflection. In panels (a) and (b), blue

568 lines represent faults.

569

570

571

572 


\section{Hydrothermal fluid paths in continental margin}

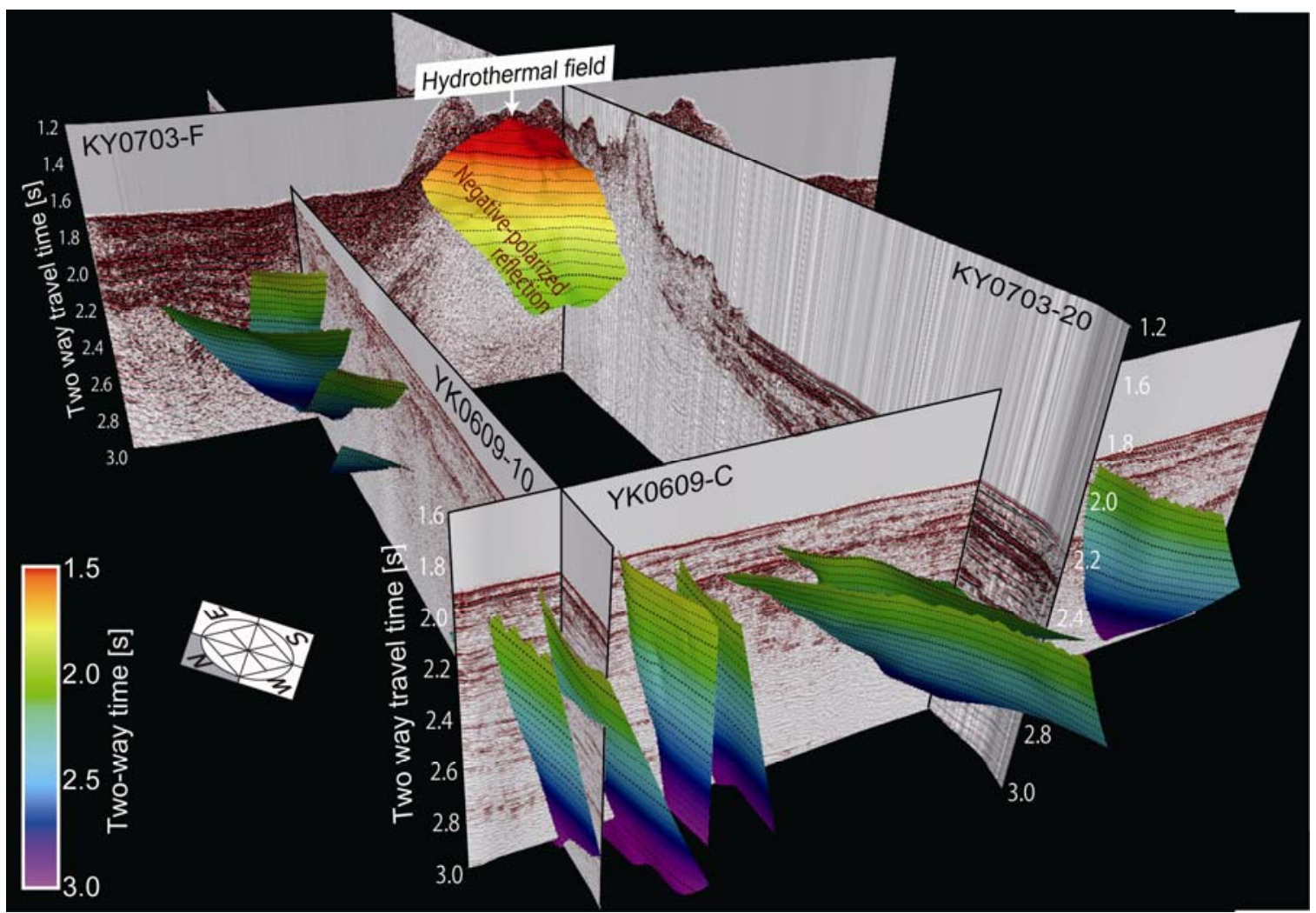

574 Figure 6. Fence diagram showing a 3D view of the seismic profiles and the

575 geometry of the negative-polarity reflector and faults within trough-fill sediments.

576 The shallowest part of the subseafloor negative-polarity reflection (top of

577 low-velocity sequence) corresponds to the location of the hydrothermal field

578 (white arrow). The faults displayed here were interpreted from intersecting

579 orthogonal 2D profiles. 
Hydrothermal fluid paths in continental margin

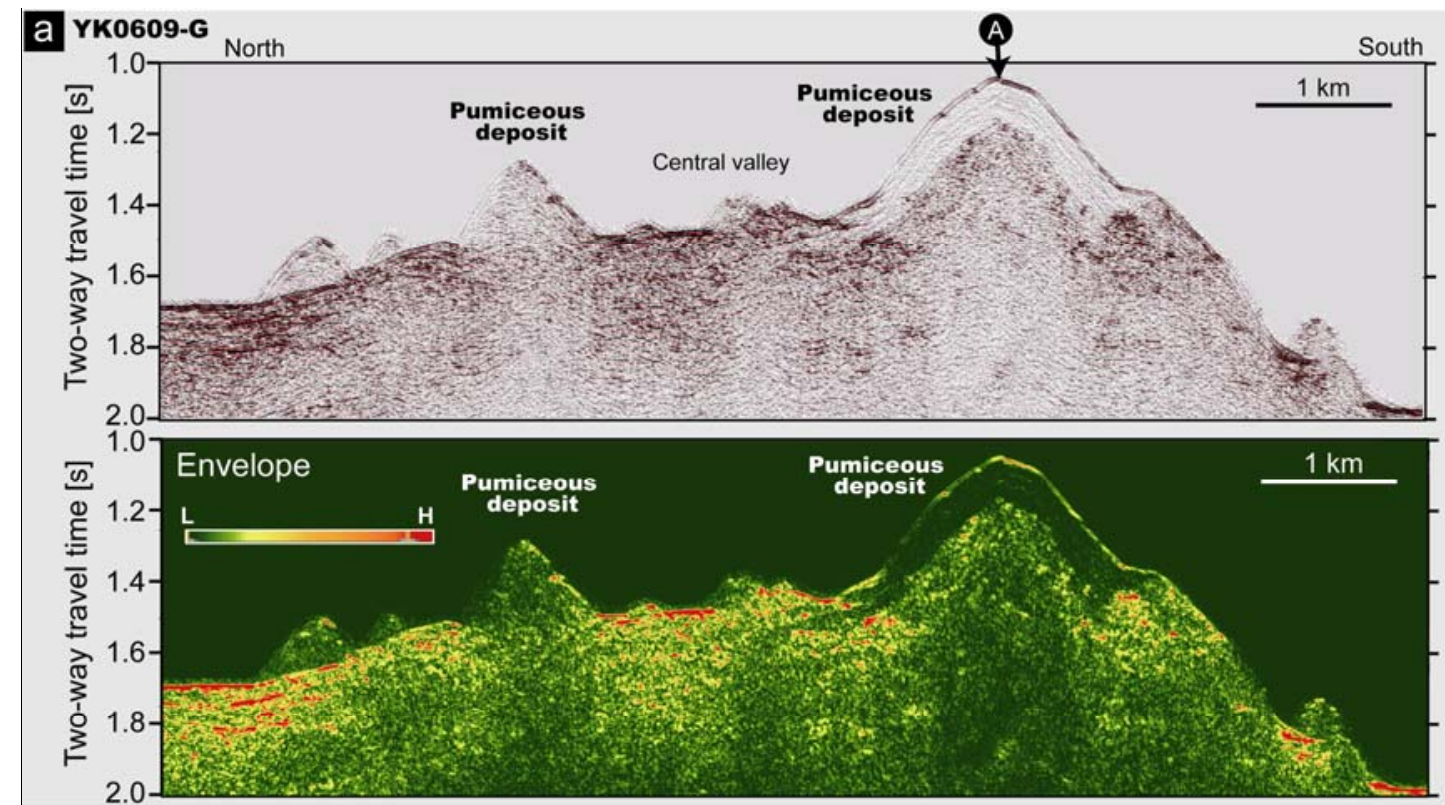

b YK0703-18 West

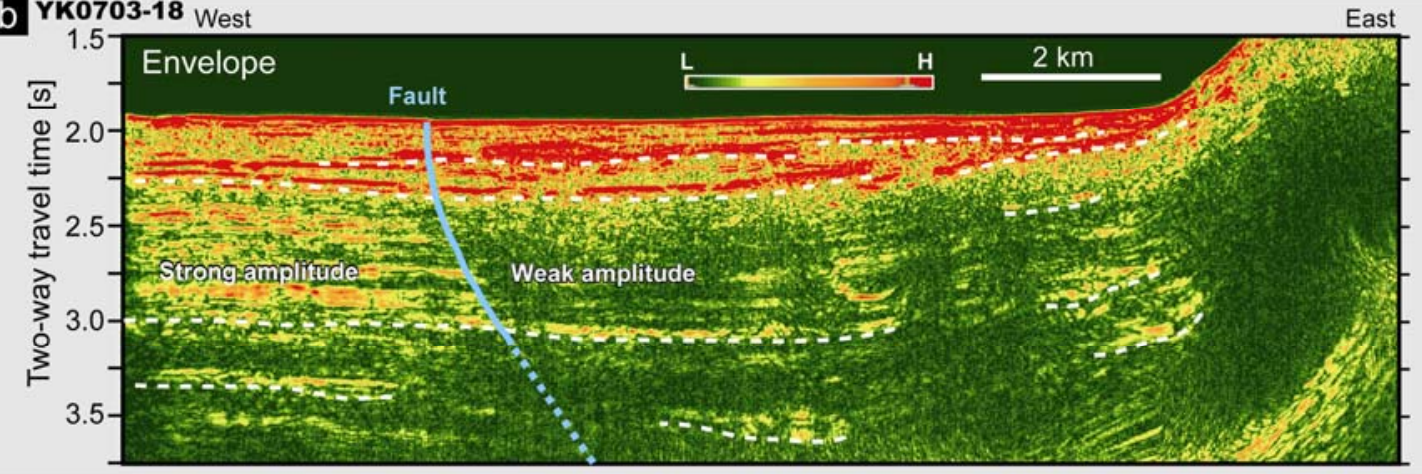

C KR1002-A02 North
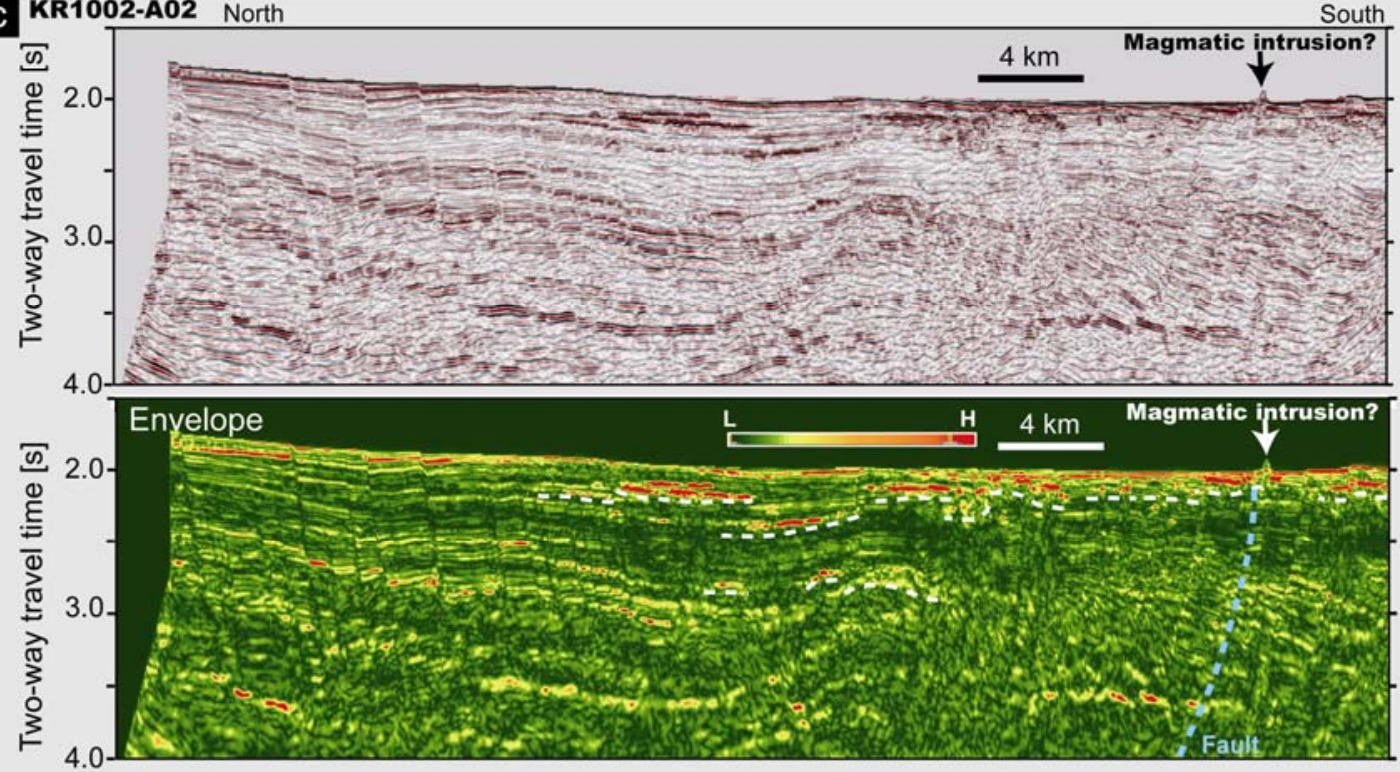

581 Figure 7. (a) N-S seismic profile (line YK0609-G2) crossing the central valley 
Hydrothermal fluid paths in continental margin

582

583

584

585

586

587

588

589

590

591

592

593

594

east of the hydrothermal field showing volcanic pumice deposits (upper), and amplitude envelope profile (lower) used to identify volcanic deposits within the sedimentary sequence. Locations of the seismic profiles are shown in Figure 1c.

(b) Amplitude envelope profile of line KY0703-18. This profile is an enlargement from Figure 5a showing interpreted volcanic deposits (white dashed lines).

Volcanic rocks within the sedimentary sequence are represented by high-amplitude, low-frequency reflections. (c) N-S seismic profile west of the Iheya North Knoll and amplitude envelope profile with interpreted volcanic deposits (white dashed lines). 
Hydrothermal fluid paths in continental margin

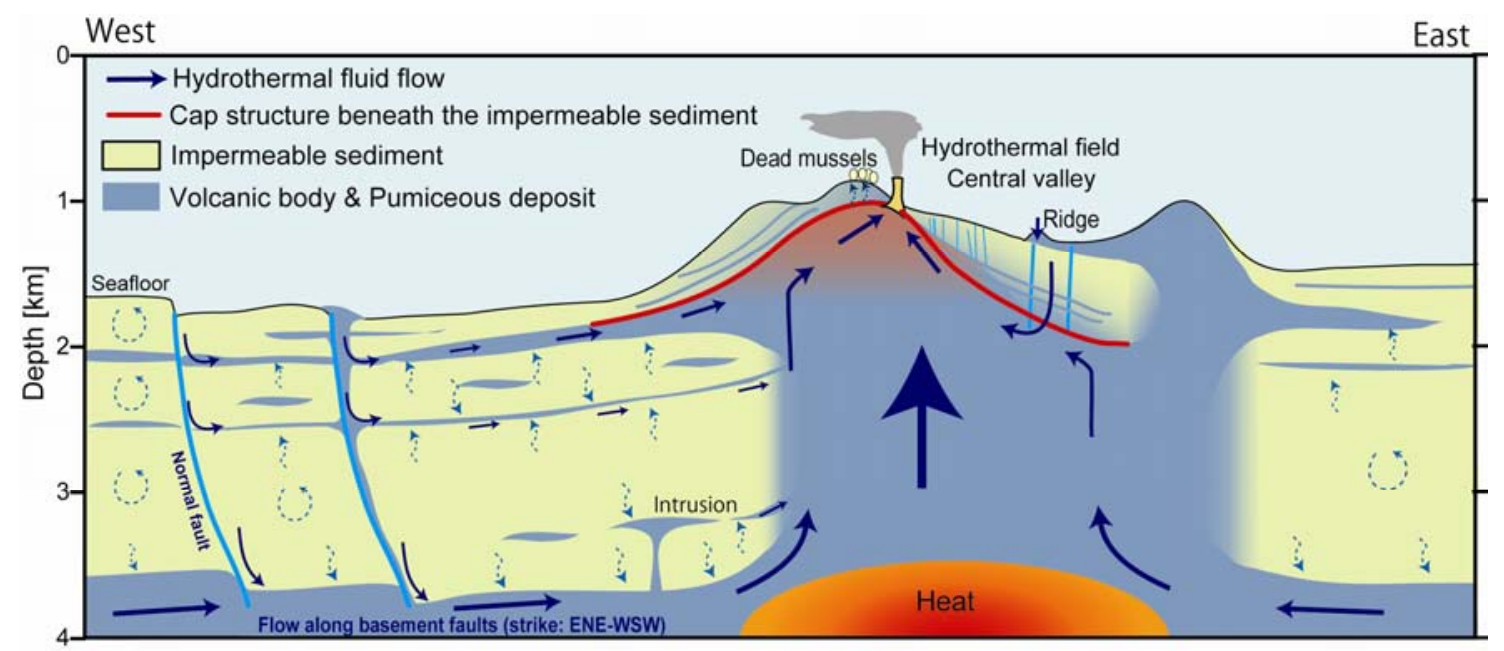

596 Figure 8. Model of the hydrothermal fluid system around the Iheya North Knoll

597 (based on seismic profile KR1002-18; Fig. 3a). Fluids flow laterally and updip

598 along permeable pumiceous layers within the sedimentary sequence and

599 laterally along basement faults within the crust. Near the knoll, fluids migrate

600 upward due to heating and are then trapped below the hydrogeologic barrier (red

601 line) and flow beneath it to vents in the hydrothermal field. 